\title{
Unemployment Determinants for Women in Spain
}

\section{Nieves Lázaro - María Luisa Moltó - Rosario Sánchez}

Abstract. Spain has one of the highest rates of unemployment among OECD countries. Some explanations for this stress the importance of unemployment duration compared with entry rates to the unemployment pool. Long-term unemployment rates are particularly high among women in Spain. The object of this paper is to investigate the determinants of unemployment duration among women. It will consider personal characteristics (education and age), family background, socio-economic variables (the number of household earners and household income) and the effect of unemployment benefits, using data from the Household Expenditure Survey 1990-91.

\section{Introduction}

The relatively low number of women employed in Spain reflects not only high unemployment rates but also low levels of activity. Although it is still the case that too few women in Spain have the opportunity of having a job, where they do, they must increasingly

Nieves Lázaro - María Luisa Moltó - Rosario Sánchez, Departamento de Análisis Económico, Universidad de Valencia, Campus de los Naranjos, Avd. de los Naranjos (Edificio Departamental Oriental), 46022 Valencia, Spain.

The authors wish to thank the Instituto Valenciano de Investigaciones Económicas for its help in data management, and an anonymous referee for helpful comments. Earlier versions of this paper were presented at the 'Primeras Jornadas de Economía Laboral' organized by the Departamento de Fundamentos de Economía e Historia Económica, Universidad de Alcalá de Henares, 7-9 June 1995 and at the '7th EALE Conference', Université Lumière Lyon 2, 7-10 September 1995. We would like to thank the audiences for interesting suggestions. A previous version of this paper has been disseminated as Working Paper WP-EC 95-15, Instituto Valenciano de Investigaciones Económicas (IVIE). The study has been supported by the Proyecto de Investigación del Programa Sectorial de Estudios de las mujeres y del Género del Plan Nacional I+D. 
compete with men for new jobs. Nevertheless, there has been an expansion in the female labour supply and a clear positive trend, apart from cyclical variations, in activity rates among middle-aged women. These tendencies are connected with sizeable increases in unemployment for those women ${ }^{1}$ and, together, can throw some light on the true dimension of the employment problem in Spain (Moltó, 1994, 1995).

The objective of this paper is to investigate unemployment among women. It is possible to distinguish two components that affect the probability of unemployment: the probability of entry into the unemployment pool and the duration of unemployment (García et al., 1986).

In the investigation of the determinants of unemployment among women the impact of preventive factors like education and age are treated in this paper with a special emphasis. Unemployment tends to be higher the lower the level of education. The economic reasoning behind this fact is that both technical and structural factors have a stronger impact on the less qualified workers. ${ }^{2}$ The employees that firms tend to dismiss first are those with lower human capital investments and this group is also subject to higher long-term unemployment rates. The importance of educational attainment of women in Spain, for both their labour market participation and employment status, is emphasized by Novales (1989). García Serrano and Toharia (1994) present a noteworthy result related to the estimated higher probability of staying in the unemployment pool for women with higher education, compared with women with secondary education. Their explanation not only takes into account the personal characteristics of the unemployed, but also the educational requirement of the new jobs generated in Spain at the time which were, principally, jobs requiring few qualifications. Nevertheless, those results need some qualification, according to their authors, as important determinants in the probability of leaving the unemployment pool were not considered. Previous labour market experience or the receipt of unemployment benefits can modify those preliminary results.

The unemployment rate is generally higher the lower the age, as both frictional and structural unemployment have a strong impact on the younger segment of the population. Gracia-Díez (1991) found that there are interaction effects between education and age on the probability of unemployment, suggesting that some highly educated women spouses may drop out of the labour force simply because 
they do not find a job, married women being in any case more sensitive to the discouraged worker effect than single women are.

Female spouses could be divided into two different groups in relation to their willingness to participate in the labour market: those who genuinely do not want to participate and those who are discouraged from participation due to the high unemployment rate. The hypothesis to be tested is whether education is an important safeguard from unemployment for women spouses, or protects women less effectively than shown by the estimates of the unemployment equation for labour market participants.

The present authors have used data from the Household Expenditure Survey to test this hypothesis. Despite the fact that this source does not go into sufficient depth regarding the labour market, it does have the relative advantage of offering exhaustive income variables and, otherwise, providing very detailed information. In any case, it does provide the principal variable of interest for the purposes of the present analysis; the number of months spent searching for a job for household members; in particular female spouses.

The length of the job search period can be used as a precise indicator of the duration of women's unemployment, given that it seems to be clear that when women do not actively search for a job they are out of the labour force and, consequently, cannot be considered unemployed (Gönül, 1992). ${ }^{3}$ The standard job search model can then be used as the framework to interpret the empirical findings. The latter is based on the assumption that the unemployed will maximize the sum of their current and expected utility.

Different policy prescriptions will be derived from different conclusions of this study. In the case in which the safeguard of education from unemployment does not prove to be sufficiently strong, as appears at first sight, more emphasis should be put into measures to facilitate labour market participation. For example, the provision of care services for dependent household members (small children and old people), instead of providing more and more education and training for women, would be a more efficient measure to combat female unemployment.

This paper is divided into six sections. The trends and developments of female unemployment are examined in Section 2. The theoretical framework and empirical model appear in Section 3. Section 4 discusses the data and definition of variables. The results are analysed in Section 5. And, finally, some concluding remarks are made in Section 6. 


\section{Trends and developments in female unemployment}

Unemployment rates for women are not only higher than they are for men in most age groups, but their evolution indicates that unemployment has become a women's problem, especially in the prime age group (see Table 1). It is precisely for women in the 25-54 age group that the unemployment rate shows an extraordinary increase with a pattern that is clearly different from that seen in other age groups. In the space of only one decade, 1983-92, the female rate doubled, whereas the male rate for this age group showed no overall increase and followed the same pattern of unemployment as for all men; a peak in 1985 followed by a decrease during the recovery period, which lasted until 1990. In the 1980s, women showed a more permanent attachment to the labour force, especially during the childbearing and child-rearing period. The participation of Spanish women in the labour market has become closer to the European Union (EU) pattern. In fact, the probability of a woman in the 25-49 age group entering the labour market during the second half of the 1980s was systematically higher in Spain than in the 10 European Community member countries prior to 1986 (see De Miguel Castaño, 1991).

The rate of unemployment among women was subject to a positive trend between 1983 and 1992. Conventionally measured as a percentage of the labour force, it stood at 26.94 percent in 1992 compared with 21.37 percent in 1983 . The considerable difference between this rate and the percentage of unemployment among the total female population of working age (9.27 percent in 1992) is due to the relatively low female activity rate. In any case, the upward change experienced by the number of women unemployed, which increased 74.89 percent in the period 1983-92, as Table 2 shows, was also accompanied by an increase of 5.6 percentage points in the female unemployment rate (see Table 1).

The mass entry of women of core working age into the labour force is one of the main causes of extraordinary increases in unemployment figures, especially for women in the 35-49 age group. Overall female unemployment grew more during the recession (between 1979 and 1986) than during the recovery, but the opposite holds for women of central age groups (30-49). This could be explained by the massive use of temporary contracts during recovery, particularly among the secondary segment of the labour force, which is constituted by women and the young.

In 1983, 58.44 percent of all unemployed women had been so for a year or more. This percentage was only slightly lower in 1992 (55.97 
Table 1. Unemployment rates by gender and age

\begin{tabular}{|c|c|c|c|c|c|c|c|c|c|c|}
\hline & \multicolumn{5}{|c|}{ Men } & \multicolumn{5}{|c|}{ Women } \\
\hline & Total & $16-19$ & $20-24$ & $5-54$ & $\begin{array}{c}55 \\
\text { or more }\end{array}$ & Total & $16-19$ & $20-24$ & $25-54$ & $\begin{array}{c}55 \\
\text { or more }\end{array}$ \\
\hline 1983 & 17.1 & 51.1 & 36.4 & 12.4 & 8.8 & 21.3 & 53.0 & 40.1 & 12.3 & 3.0 \\
\hline 1984 & 20.3 & 55.6 & 41.6 & 15.0 & 12.0 & 24.9 & 59.7 & 47.0 & 14.9 & 4.6 \\
\hline 1985 & 20.3 & 52.8 & 42.9 & 15.4 & 11.3 & 25.8 & 59.0 & 48.8 & 16.8 & 4.8 \\
\hline 1986 & 19.0 & 48.5 & 40.9 & 13.9 & 12.0 & 26.0 & 57.5 & 47.6 & 17.3 & 5.8 \\
\hline 1987 & 16.0 & 43.9 & 32.0 & 12.0 & 9.4 & 27.9 & 54.8 & 46.7 & 20.7 & 6.5 \\
\hline 1988 & 14.1 & 36.2 & 28.7 & 10.7 & 8.8 & 26.9 & 50.0 & 44.4 & 21.3 & 6.4 \\
\hline 1989 & 12.7 & 30.6 & 26.7 & 9.7 & 8.9 & 24.8 & 43.7 & 39.4 & 21.2 & 6.4 \\
\hline 1990 & 11.9 & 29.4 & 24.4 & 9.3 & 7.9 & 23.8 & 41.7 & 37.8 & 20.6 & 6.3 \\
\hline 1991 & 12.8 & 30.9 & 24.6 & 10.3 & 9.1 & 24.4 & 40.3 & 38.0 & 21.7 & 7.1 \\
\hline 1992 & 16.1 & 38.0 & 32.1 & 13.1 & 10.3 & 26.9 & 48.4 & 41.6 & 24.3 & 7.6 \\
\hline
\end{tabular}

Source: INE, EPA (4th quarter).

percent), a decrease which contrasts with the stability of female longterm unemployment (two years or more), standing at 35 percent, both at the beginning and at the end of the decade (see Table 3).

The percentage change for unemployed women with previous labour market experience was also subject to an increasing trend, rising from 43.21 percent in 1983 to 71.29 percent in 1992, and is

Table 2. Percentage change of female unemployment by age

\begin{tabular}{|c|c|c|c|c|c|c|}
\hline \multirow[b]{2}{*}{ Age group } & \multicolumn{2}{|c|}{ 1983-1992 } & \multicolumn{2}{|c|}{ 1987-1992 } & \multicolumn{2}{|c|}{ 1983-1986 } \\
\hline & Thousands & Percentage & Thousands & Percentage & Thousands & Percentage \\
\hline $16-19$ & -74.4 & -30.4 & -104.4 & -38.01 & 1.5 & 0.61 \\
\hline $20-24$ & 57.5 & 18.03 & -79.6 & -17.45 & 90.8 & 28.46 \\
\hline $25-29$ & 165.2 & 119.11 & 57 & 23.09 & 74.6 & 53.79 \\
\hline $30-34$ & 151.5 & 271.51 & 78.7 & 61.2 & 39.4 & 70.61 \\
\hline $35-39$ & 127.1 & 402.22 & 69.6 & 78.11 & 17.2 & 54.43 \\
\hline $40-44$ & 96.1 & 497.93 & 51.3 & 80.03 & 16.3 & 84.46 \\
\hline $45-49$ & 66 & 611.11 & 40.7 & 112.74 & 14.6 & 135.19 \\
\hline $50-54$ & 24.8 & 137.78 & 8.1 & 23.34 & 7.1 & 39.44 \\
\hline $55-59$ & 14.8 & 110.45 & 3 & 11.9 & 3.9 & 29.1 \\
\hline $60-64$ & 8.4 & 280 & 3.7 & 48.05 & 6.5 & 216.67 \\
\hline $65-69$ & 0.9 & 0 & -0.2 & -18.18 & - & - \\
\hline $70+$ & 1.9 & 0 & 1.9 & 0 & - & - \\
\hline Total & 639.8 & 74.89 & 129.8 & 9.51 & 271.9 & 31.88 \\
\hline
\end{tabular}

Source: INE, EPA (4th quarter). 
very high owing to low levels of departure. Note that this trend exists among younger age groups as well. Among older women, on the other hand, the number of first job seekers grew.

The growing numbers of unemployed women with previous labour market experience is a reminder of the important role that temporary contracts play in Spain in the explanation of unemployment spells. As Table 4 shows, nearly 90 percent of women on temporary contracts did not find a permanent job (indefinite contract) which contrasts with less than 1 percent of women who did not want a permanent job. ${ }^{4}$

According to Toharia (1991), the increase in the number of temporary contracts for women has been an important factor affecting the rise in long-term unemployment among women with previous labour market experience. In fact, over the period 198790 , the percentage of women with labour market experience who left employment through the ending of contracts rose from 54.7 percent to 71.2 percent.

It is also interesting to consider the relationship between employment sector and temporary contracts. The changing tendency toward the use of temporary contracts for women is shown, by industry, in Table 5.

Between 1987 and 1992, the 34.47 percent increase in female employment in the service sector was due mainly to the increase in the use of temporary contracts (151.04 percent). In the case of

Table 3. Women's unemployment duration by search time in 1992

Thousands (percentage distribution)

\begin{tabular}{lcccccc}
\hline & Unemployed & $<$ 6 months & $\mathbf{6}-\mathbf{1 2}$ months & $\mathbf{1 - 2}$ years & $\mathbf{2}$ or more & Non-classified \\
\hline Total & $1,494.1$ & 418.8 & 225.7 & 311 & 525.3 & 13.7 \\
& $(100)$ & $(28)$ & $(15.1)$ & $(20.8)$ & $(35.2)$ & $(0.9)$ \\
$16-19$ & 170.3 & 70.8 & 29.7 & 42.7 & 25.5 & 1.7 \\
& $(100)$ & $(41.5)$ & $(17.4)$ & $(25.1)$ & $(15)$ & $(1.0)$ \\
$20-29$ & 680.4 & 200.7 & 104.9 & 141.1 & 227.7 & 6.2 \\
& $(100)$ & $(29.5)$ & $(15.4)$ & $(20.7)$ & $(33.5)$ & $(0.9)$ \\
$30-44$ & 481.4 & 109.2 & 72.8 & 98.7 & 196.1 & 4.7 \\
& $(100)$ & $(22.7)$ & $(15.1)$ & $(20.5)$ & $(40.7)$ & $(1.0)$ \\
$45-54$ & 119.6 & 27.6 & 12.2 & 21.5 & 57.2 & 1 \\
& $(100)$ & $(23.1)$ & $(10.2)$ & $(18.1)$ & $(47.8)$ & $(0.8)$ \\
55 or over & 42.4 & 10.5 & 6.1 & 7 & 18.8 & 0.1 \\
& $(100)$ & $(24.7)$ & $(14.3)$ & $(16.5)$ & $(44.3)$ & $(0.2)$ \\
\hline
\end{tabular}

Source: INE, EPA (4th quarter). 
Table 4. Reason for temporary contract, women

\begin{tabular}{lccrrr}
\hline & \multicolumn{2}{c}{1987} & & \multicolumn{2}{c}{1992} \\
\cline { 2 - 3 } \cline { 5 - 6 } Reason & Thousands & Percentage & & Thousands & Percentage \\
\hline Total & 564.9 & 100 & & $1,142.5$ & 100 \\
Indefinite contract not found & 496.3 & 87.86 & & 990.3 & 86.68 \\
Indefinite contract rejection & 5.1 & 0.9 & & 7.2 & 0.63 \\
Other reasons & 58.9 & 10.43 & & 107.1 & 9.37 \\
Not known & 4.6 & 0.81 & & 37.9 & 3.32 \\
\hline
\end{tabular}

Source: INE, EPA (4th quarter).

Table 5. Percentage change of women employees by indefinite/temporary employment by industry, 1987-92

\begin{tabular}{lrrrrrrrr}
\hline & \multicolumn{2}{c}{ Total } & & \multicolumn{2}{c}{ Indefinite } & & \multicolumn{2}{c}{ Temporary } \\
\cline { 2 - 3 } \cline { 7 - 8 } & Thousands & Percentage & & Thousands & Percentage & & Thousands & Percentage \\
\hline Total & 666.0 & 28.35 & & -10.0 & -0.53 & & 676.0 & 135.84 \\
Agriculture & 10.8 & 20.53 & & -7.3 & -39.67 & & 18.1 & 52.92 \\
Manufacturing & 19.2 & 3.83 & & -92.5 & -23.49 & & 111.7 & 104.1 \\
Construction & 22.4 & 151.35 & & 8.0 & 72.73 & & 14.4 & 378.95 \\
Services & 613.6 & 34.47 & & 81.8 & 5.73 & & 531.8 & 151.04 \\
\hline
\end{tabular}

Source: INE, EPA (4th quarter).

manufacturing, temporary contracts also play a very important role for women's employment. Despite the fall in the number of women employed under indefinite contracts in manufacturing, there was a small rise of 3.83 percent in total employment of women, caused by the significant increase of temporary contracts for women in this sector.

\section{The model}

\subsection{Theoretical framework}

Broadly speaking, the theoretical framework takes the form of the standard job search model (Holzer, 1988). This assumes that the unemployed will maximize the sum of current and expected utility, which is a function of the reservation wage, the job offer 
probability function and the wage offer distribution. The theoretical model assumes that the provision of unemployment benefits raises the reservation wage, and thus reduces the probability of accepting a job offer which, in turn, increases the duration of unemployment.

The institutional set-up is an important contributory factor in reducing the randomness of the job search process (Molto et al., 1994). Different job search modes involve different monetary and time costs. Job search through relatives is presumed to be the most frequently used method by married women. Where the husband is in employment, the probability of women finding a job is increased; they are therefore likely to exit the unemployment pool earlier than married women living in households where the principal earner is unemployed. ${ }^{5}$ Since job search requires more time for the wives of unemployed workers and since the opportunity cost for all wives is high, then the effect of having an unemployed husband is having to face a longer search. Unemployment duration is thus increased.

According to Holzer (1988), the unemployed will choose a job search mode and intensity that maximizes current and expected utility. Current utility depends on income minus the monetary cost of the job search and leisure minus the time cost of the job search. Expected utility, on the other hand, depends on the probability of being employed and unemployed in the future. These probabilities are a function of the job offer probability function and the wage offer distribution. The expected value of the utility function of being employed in the future, given the reservation wage and the utility of being unemployed in the next period, are the multiplying factors of the probability of employment and unemployment, respectively. More formally, the unemployed maximize expected utility function $U_{t}$ in $t$ :

$$
\begin{aligned}
U_{t}= & V\left(Y-\sum c_{i} B_{i}, L-\sum B_{i}\right)+\pi\left(B_{1}, B_{2}\right)[1-f(\tilde{w})] E \psi[(w) / \tilde{w}] \\
& +\left\{1-\pi\left(B_{1}, B_{2}\right)[1-f(\tilde{w})]\right\} U_{t+1},
\end{aligned}
$$

where $\tilde{w}$ is the reservation wage, $\pi$ is the probability density function of job offers, $f(\tilde{w})$ is the wage offer distribution, $B_{i}$ is the search intensity of the i-method, which is associated with a given monetary cost $\left(c_{i}\right), V$ is current utility, $\psi$ is the utility function of 
employment in $t+1, Y$ is income and $L$ leisure. In addition, the productivity of each search method decreases when the cost increases, the cost and productivity of each search method varying according to the individual, depending on their socio-economic characteristics.

According to Andrés et al. (1989), the analysis of unemployment duration determinants is equivalent to analysing the probability of exiting the unemployment pool, which can be broken down into the probability of receiving a job offer with an associated wage offer and the probability of accepting it. Among married women, the probability of leaving the unemployment pool directly relates to the employment status of other family members, particularly husbands. Where the latter are employed, the probability of women receiving a job offer clearly increases. This is due to the greater availability of information about vacancies in the labour market, the employed husband acting as an information channel regarding vacancies. Conversely, where the husband is unemployed the wife has no access to that information. The probability of exiting the unemployment pool is also reduced by the presence of small children in the household. In this case, the higher reservation wage will decrease the probability of accepting a wage offer. The receipt of unemployment benefits will have a similar effect on the probability of wage offer acceptance, again due to a higher reservation wage. Personal characteristics such as age and educational attainment as indicators of labour supply factors have an ambiguous effect on the probability of unemployment duration. Although education increases the probability of receiving a job offer, ceteris paribus, it also decreases the probability of accepting a wage offer, as the reservation wage will be higher according to educational attainment. On the other hand, the probability of receiving a job offer decreases with age as does the reservation wage; the probability of accepting a wage offer thus increases. Finally, demand-side factors such as occupation, professional status and location (as an indicator of regional unemployment rates) are expected to have a significant impact on unemployment duration through the probability of receiving a job offer.

\subsection{Empirical model}

Given that the main variable of interest is the length of time that elapses from the beginning of the unemployment spell until the 
measurement is taken, the best-suited empirical model takes the form of a parametric model of duration.

According to the proportional hazard model, the length of unemployment spell is represented by a random variable (see, for example, Greene, 1993). Regression analysis can be applied to the sample of observed spells. Unfortunately, in the present case all sample observations are incomplete spells. In fact, the available data imply that the measurement was made while the process was ongoing. Consequently, it is not possible to calculate expected unemployment duration conditioned on a set of covariates measured in the observation period. The present authors have concentrated, instead, on the differential impact of unemployment duration determinants for women living in different family environments. This analysis is of interest because it is assumed that the process of accumulation of information about job opportunities will be different for insiders - those who have one or more family members in employment - compared with outsiders - those living in households with unemployed members only.

The empirical analysis is divided into two parts: the estimation of the probability of unemployment and unemployment duration. In order to draw inferences for the population of all married women, the authors have estimated a participation equation to correct for sample selection bias, in the first place. This is followed by the estimation of a logit model for the probability of unemployment with sample selection correction. ${ }^{6}$ In addition, an unemployment equation is estimated without sample selection correction, for comparison.

Finally, an ordered logit model is specified in order to estimate the impact of several determinants on the probability of distribution of unemployment duration.

The available information for testing the influence of the main factors affecting unemployment duration requires an econometric specification of the general class of discrete choice models (see Maddala, 1983).

Given that unemployment duration is considered here in a discrete form (by rank), the specified equation for the dependent variable is of the ordered logit class models. Accordingly, we can consider the following linear relationship between the vector of independent variables $x$ and the unobserved dependent variable $y$ :

$$
y^{*}=b x+u
$$

following $u$ the logit distribution with $E(u)=0$, and $\sqrt{E\left(u^{2}\right)}=1.81$. 
The observed counterpart to $y^{*}$ is $y$, in our case the rank of unemployment duration. Each woman is classified accordingly. For example, if the unemployment duration of woman $i$ is less than $\mu(0)$, the variable $y$ is equal to zero, and so forth.

$$
\begin{aligned}
& y=0 \text { with } y^{*} \leqslant 0 \\
& y=1 \text { with } 0<y^{*} \leqslant \mu(1) \\
& y=2 \text { with } \mu(1)<y^{*} \leqslant \mu(2) \\
& y=3 \text { with } \mu(2)<y^{*} \leqslant \mu(3) \\
& y=4 \text { with } \mu(3)<y^{*} .
\end{aligned}
$$

The $\mu(j)$ coefficients are the quantitative limits of each rank. Given the identification problem and that $y$ is observed only ordinally we shall use the normalization rule of a logit model. is:

The probability that woman $i$ is in $j$ unemployment duration step

$$
\begin{aligned}
\operatorname{Prob}[y=j]=[1 /[1+\exp (b x-\mu(j))]] & \\
& -[1 /[1+\exp (b x-\mu(j-1))]] .
\end{aligned}
$$

Equation [2] permits the analysis of the impact of different female characteristics on the probability distribution of unemployment duration.

\section{Data and variables}

\subsection{Data}

Recent data containing information on labour force participation, earnings and socio-economic characteristics of households are available from the Household Expenditure Survey (1990-91) (EPF). This survey is a good data source for income and expenditure; however, it also contains information relevant to the study of the labour market situation of specific groups like female spouses. This data source is unique in the sense that personal characteristics are not the only variables of the situation of women in the labour market, family factors also playing a very important role. The sub-sample made up of all women spouses, formed by 14,067 observations, can then be used to estimate a participation equation; the sub-sample of those women spouses who are either employed or unemployed (3,598 observations) to 
estimate an unemployment equation; and, finally, the sub-sample of those unemployed with previous labour market experience (617) to estimate the duration of unemployment. The estimated participation rate for women spouses, according to the EPF sample, was 26.1 percent in 1990-91 and the unemployment rate was 18.5 percent (617 unemployed with previous labour market experience +50 unemployed without previous labour market experience).

Next, some comparisons are established with the most relevant data source for labour market variables, the Labour Force Survey (EPA) (see Tables 6 and 7), in order to show that our EPF subsample of women spouses is adequate to draw inferences applicable to the population of married women in Spain.

There are minor discrepancies in the unemployment rates for women spouses between our sample estimate (18.5 percent) and the labour force estimate (19.3 percent), but greater discrepancies are found in the distribution of women spouses by unemployment duration. As Table 7 shows, very long-term unemployed women

Table 6. Active and unemployed women spouses

\begin{tabular}{lrcc}
\hline & Active & Unemployed & $\begin{array}{c}\text { Unemployment } \\
\text { rate (\%) }\end{array}$ \\
\hline EPA 1991 & $2,477,000$ & 479,100 & 19.34 \\
EPF 1990-91 & 3,598 & 667 & 18.54 \\
\hline
\end{tabular}

Source: EPA (1st quarter 1991) and EPF (1990-91).

Table 7. Unemployment duration of women spouses

\begin{tabular}{lccccc}
\hline & \multicolumn{2}{c}{ EPF 1990-91 } & & \multicolumn{2}{c}{ EPA 1991 } \\
\cline { 2 - 3 } \cline { 5 - 6 } $\begin{array}{l}\text { Months } \\
\text { searching }\end{array}$ & $\begin{array}{l}\text { Women } \\
\text { spouses }\end{array}$ & $\begin{array}{c}\text { Percentage } \\
\text { distribution }\end{array}$ & & $\begin{array}{c}\text { Women spouses } \\
\text { (thousands) }\end{array}$ & $\begin{array}{c}\text { Percentage } \\
\text { distribution }\end{array}$ \\
\hline$<6$ months & 225 & 33.7 & & 126.6 & 26.3 \\
$6-11$ months & 119 & 17.9 & & 65.5 & 13.6 \\
$12-24$ months & 178 & 26.7 & & 96.2 & 19.9 \\
$>24$ months & 145 & 21.7 & & 189.7 & 39.3 \\
Non-classified & - & - & & 4.2 & 0.9 \\
Total & 667 & 100 & & 482.3 & 100 \\
\hline
\end{tabular}

Source: authors' own calculation from EPA (1st quarter 1991) and EPF (1990-91).

(C) Fondazione Giacomo Brodolini and Blackwell Publishers Ltd 2000. 
spouses are under-represented in our EPF sample, while very short-term unemployed are over-represented. Even if the percentage of women searching for more than one year in our sample (48.4 percent) is not much lower than the corresponding percentage in the Labour Force Survey (59.2 percent), most of the discrepancy could be attributable to the different percentage of women spouses unemployed for more than two years.

Given that women with no labour market experience are the most vulnerable to very long-term unemployment, the underrepresentation of this group in the sample would account for the observed difference. It has to be noted that in our sample the percentage of women unemployed without previous labour market experience ( 7.5 percent) is much lower than the corresponding percentage in the Labour Force Survey, this percentage being around 40 percent.

In any case, as the specified model for unemployment requires information on the more recent job and socio-economic category, women without labour market experience were left out of the sample used for estimation.

\subsection{Variables}

The dependent variables are defined as follows:

(i) Labour market participation is a dummy variable taking value 1 if the woman participates and 0 for nonparticipants in the previous week.

(ii) Unemployment is a dummy variable, equal to 1 if the woman is unemployed and 0 otherwise.

(iii) Unemployment duration is quantified by rank, taking values from 0 up to 4 ; it takes value 0 if she is searching for up to 6 months; value 1 if she was searching from 7 to 12 months; value 2 if the searching period is between 13 and 18 months, value 3 between 19 and 24 months, and finally value 4 for more than 24 months.

The explanatory variables are defined as follows:

(i) Size of town is a dummy variable taking value 1 if the woman lives in a town of more than 20,000 inhabitants and 0 otherwise (S-town). 
(ii) Number of household earners (N-earn) is a quantitative variable, which is equal to the total number of household earners, excluding the wife.

(iii) Household income is a quantitative variable (H-income), measuring the household income excluding the labour income of the wife.

(iv) Unemployment benefit is a dummy variable taking value 1 if the woman receives unemployment subsidy and 0 otherwise (Ubenef).

(v) Region of residence is a set of six dummies:

- Madrid (reference category);

- North West: Galicia, Asturias, Cantabria (Northwest);

- North East: País Vasco, Navarra, Rioja, Aragón (Northeast);

- Central: Castilla-León, Castilla-La Mancha, Extremadura (Centre);

- East: Cataluña, C. Valenciana, Baleares (East);

- South: Andalucia, Murcia, Canarias, Ceuta y Melilla (South).

(vi) Occupation in the latter job comprises a set of five dummies:

- professionals, technicians and armed forces officials, legislators, senior government officials and managers (reference category);

- clerks (Occu3);

- service and sales workers (Occu4);

- agricultural and related workers (Occu5);

- craft workers, plant and machine operators and assemblers (Occu6).

(vii) Socio-economic category of more recent job consists of three dummies: the first takes value 1 if the woman was an employer in the previous week and 0 otherwise (reference category); (Sit2) takes value 1 if the woman was a family worker and 0 otherwise; (Sit3) takes value 1 if the woman is an employee.

(viii) Education consists of a set of four dummies, the reference category being under primary education:

- primary education (Ed2);

- secondary education(Ed3);

- higher education (Ed4). 
(ix) Type of household is a dummy variable taking value 1 for couples with children and 0 otherwise (T-house).

(x) Age is a set of four dummies:

- women 28-39 (Age2);

- women 40-51 (Age3);

- women 52-65 (Age4);

- women 16-28, which is the reference category

(xi) SitCF is a dummy variable, taking value 1 if the principal earner is in employment and 0 otherwise.

\section{Results}

\subsection{Participation equation}

The estimated percentage of women participants living with their partner is 26.1 percent. Most coefficients are significant at the 5 percent level, as shown in Table 8. First, there are significant differences in the probability of participation by region. All, except the Central and South regions, have a positive impact on the probability of participation with respect to the reference category which is the Madrid region. In any case, the impact is comparatively greater in the East and Northwest, than in the Northeast.

Looking now at the effect of the household environment on the participation decision of married women, we find that when the principal earner is in employment (SitCF), the probability of female participation does not significantly differ from when the principal earner is not in employment. However, as the number of income earners in the household increases, so does the probability of women's participation. This reflects the fact that for any given total household income level, the contribution of each household member is smaller and, consequently, the participation of additional workers is necessary to maintain the living standard of the household. This is the typical case where the additional worker effect will predominate over the discouraged worker effect of the secondary earner. In any case, the probability of participation significantly decreases as family income (H-incom) increases.

Finally, those personal characteristics basic to the participation decision - age and education - have the expected impact. The age variable has a significant negative effect on the probability of participation while educational attainment has a positive influence. 
Table 8. Participation equation. Binomial logit model

\begin{tabular}{llll}
\hline Variables & Coefficient & $\boldsymbol{t}$-ratio & Mean of $\boldsymbol{x}$ \\
\hline Constant & -0.93581 & -5.422 &
\end{tabular}

Size of town. Reference category: fewer than $\mathbf{2 0 , 0 0 0}$

S-town

$-0.92948 \mathrm{E}-01$

$-1.862$

0.73292

Number of earners

N-earn

0.10248

3.693

1.6844

Total household income

$\mathrm{H}$-income

$-0.229 \mathrm{E}-06$

$-10.290$

$0.215 \mathrm{E}+07$

Region of residence. Reference category: Madrid

$\begin{array}{llll}\text { Northwest } & 0.63896 & 4.915 & 0.11644 \\ \text { Northeast } & 0.34181 & 2.669 & 0.15291 \\ \text { Centre } & 0.13508 \mathrm{E}-01 & 0.108 & 0.25798 \\ \text { East } & 0.71485 & 5.727 & 0.18064 \\ \text { South } & 0.20182 & 1.623 & 0.25315\end{array}$

Education. Reference category: primary education

$\begin{array}{llrl}\mathrm{Ed} 2 & 0.73854 \mathrm{E}-01 & 1.201 & 0.63972 \\ \mathrm{Ed} 3 & 0.98007 & 10.930 & 0.80045 \mathrm{E}-01 \\ \mathrm{Ed} 4 & 2.2830 & 22.000 & 0.62771 \mathrm{E}-01\end{array}$

Type of household. Reference category: household without children
T-house
0.20526
3.864
0.25535

Situation of principal earner. Reference category: inactive and unemployed
SitCF
0.80980E-01
1.278
0.74892

Age. Reference category: $16-28$

$\begin{array}{llrl}\text { Age2 } & -0.41463 \mathrm{E}-01 & -0.524 & 0.30284 \\ \text { Age3 } & -0.50714 & -5.973 & 0.30205 \\ \text { Age4 } & -1.3427 & -14.405 & 0.32558\end{array}$

Notes: $N=14,067$.

Log-likelihood $=-6,974.083$.

Restricted (slopes $=0$ ) $\log -\mathrm{L}=-7,998.386$.

Chi-squared $(16)=2,048.605$.

\subsection{Unemployment equation}

The estimated coefficients of the binomial logit model of unemployment, unconditional on participation, appear in Table 9. The coefficients corresponding to both personal characteristics and environmental variables are significant at the 5 percent level. 
Table 9. Unemployment equation. Binomial logit model with sample selection (logit selection equation based on participation)

\begin{tabular}{llcc}
\hline Variable & Coefficient & $\boldsymbol{t}$-ratio & Mean of $\boldsymbol{x}$ \\
\hline Constant & 0.88659 & 7.914 &
\end{tabular}

Size of town. Reference category: fewer than $\mathbf{2 0 , 0 0 0}$

$\begin{array}{llll}\text { S-town } & 0.40051 \mathrm{E}-01 & 1.928 & 0.75486\end{array}$

Region of residence. Reference category: Madrid
Northwest
$-0.14898$
$-2.597$
0.14036
Northeast
$-0.78789 \mathrm{E}-01$
$-1.473$
0.15509
Centre
$-0.62214 \mathrm{E}-01$
$-1.209$
0.21234
East
$-0.12633$
$-2.269$
0.23513
South
$0.26030 \mathrm{E}-02$
0.050
0.22679

Education. Reference category: primary education
Ed2
$-0.49354 \mathrm{E}-01$
$-1.672$
0.55531
Ed3
$-0.22969$
$-5.175$
0.13924
Ed4
$-0.44206$
$-6.772$
0.16620

Type of household. Reference category: household without children
T-house
0.42090E-02
0.203
0.31184

Situation of principal earner. Reference category: inactive and unemployed
SitCF
$-0.11415$
$-4.274$
0.84380
Age. Reference category: $16-28$

$\begin{array}{lcrl}\text { Age2 } & -0.63215 \mathrm{E}-01 & -2.275 & 0.45636 \\ \text { Age3 } & -0.77289 \mathrm{E}-01 & -2.112 & 0.28155 \\ \text { Age4 } & 0.73205 \mathrm{E}-02 & 0.123 & 0.14758 \\ \text { Lambda } & -0.34846 & -4.716 & 1.0865\end{array}$
Notes: $N=3,598$.
Log-likelihood $=0.1545996 \mathrm{E}+04$.
Amemiya Pr. Criterion $=0.8682578 \mathrm{E}+00$.
Akaike Info. Criterion $=0.1395100 \mathrm{E}+00$.
Selection Criterion (rho) $=-0.80314$.

First, for women whose husband is in employment (SitCF), the probability of unemployment decreases compared with those whose husband is not in employment. This result supports our initial hypothesis that job opportunities would be greater among women who are in close contact with principal earners active in the labour market.

Second, as regards personal characteristics, the results show that educational attainment (Ed) has a negative impact on the 
probability of unemployment. In addition, the estimated coefficients increase in absolute value with educational level, which implies that women with higher education have a comparatively lower probability of unemployment than those not educated beyond secondary level. Primary-level attainment is used here as the reference category. Nevertheless, when comparing the previous estimates with all the conditional estimated coefficients for the educational dummies appearing in Table 10, it is very interesting to note that the positive effect of education in decreasing the probability of unemployment for married women, irrespective of their decision to participate in the labour market, is not as great as it seemed at first. In other words, although education is definitely a safeguard for women against unemployment, our results show that, once the sample selection bias is taken into account, the educational safeguard is weaker. The straightforward implication of this finding is that married women with higher educational attainment may also be discouraged from labour market participation due to high unemployment rates. Consequently, unconditional estimates of education will give us a more complete picture of the real impact of education on the probability of unemployment than the conditional estimates that have appeared in the literature so far. The emphasis legitimately put by some authors on the importance of education of women both for labour market participation and employment status (e.g. Novales, 1989) should be reconsidered in the light of the above results.

The age dummies (Age) also show a significant negative impact on the probability of unemployment. The estimated coefficients also increase in absolute value, implying that the higher the age, the smaller the probability of unemployment. Given that the age variable can be considered in our model as a proxy for experience, apart from the cohort effect itself, both the sign and the absolute values can be interpreted as experience effects. If the unconditional estimates of the age dummies are compared with the conditional estimates appearing in Table 10, as was done previously with the educational dummies, a similar conclusion can be drawn. Also in this case, where the differences between the unconditional (corrected for selectivity bias) and the conditional estimates are quite important, we can draw the interesting conclusion that the age variable, as an approximate indicator of experience, has a less negative impact on the probability of unemployment in any given situation, irrespective of participation. 
Table 10. Unemployment equation. Binomial logit model

\begin{tabular}{lccc}
\hline Variable & Coefficient & $\boldsymbol{t}$-ratio & Mean of $\boldsymbol{x}$ \\
\hline Constant & 0.17779 & 0.524 &
\end{tabular}

Size of town. Reference category: fewer than $\mathbf{2 0 , 0 0 0}$
S-town
0.13510
1.245
0.75486

Region of residence. Reference category: Madrid

$\begin{array}{lrrr}\text { Northwest } & -0.31602 & -1.117 & 0.14036 \\ \text { Northeast } & -0.19307 & -0.696 & 0.15509 \\ \text { Centre } & -0.38792 & -1.411 & 0.21234 \\ \text { East } & -0.13672 & -0.512 & 0.23513 \\ \text { South } & 0.22552 & 0.845 & 0.22679\end{array}$

Education. Reference category: primary education

$\begin{array}{llll}\text { Ed2 } & -0.32528 & -2.318 & 0.55531 \\ \text { Ed3 } & -0.76337 & -4.068 & 0.13924 \\ \text { Ed4 } & -1.6061 & -7.434 & 0.16620\end{array}$

Type of household. Reference category: household without children
T-house
0.27834
2.681
0.31184

Situation of principal earner. Reference category: inactive and unemployed
SitCF
$-0.76040$
$-6.095$
0.84380
Age. Reference category: 16-28

\begin{tabular}{llll} 
Age2 & -0.38839 & -2.876 & 0.45636 \\
Age3 & -1.0825 & -6.606 & 0.28155 \\
Age4 & -1.3457 & -6.970 & 0.14758 \\
\hline
\end{tabular}

Notes: $N=3,598$.

Log-likelihood $=-1,594.412$.

Restricted (slopes $=0$ ) Log- $\mathrm{L}=-1,725.080$.

Chi-squared $(14)=261.3369$.

Finally, there are significant differences in the Northwest and East regions, with respect to the region of Madrid, having a significant negative impact on the unconditional probability of unemployment for women spouses. Note that in the Northwest and East regions the participation of married women in the labour market is significantly higher than in Madrid, as the estimated participation equation shows (see Table 8). This is due, partly, to the better prospects of finding a job for women in these regions than in the area of Madrid. It is then reasonable to believe that they also face a lower probability of unemployment in the 
Table 11. Unemployment duration equation. Ordered probit model

\begin{tabular}{lccc}
\hline Variable & Coefficient & $\boldsymbol{t}$-ratio & mean of $\boldsymbol{x}$ \\
\hline Constant & 4.1592 & 5.054 &
\end{tabular}

Size of town. Reference category: fewer than $\mathbf{2 0 , 0 0 0}$

S-town

$$
0.36070
$$

1.660

0.75365

Region of residence. Reference category: Madrid

$\begin{array}{llll}\text { Northwest } & 0.25625 & 0.487 & 0.11021 \\ \text { Northeast } & 0.62973 & 1.172 & 0.13290 \\ \text { Centre } & 0.35950 & 0.708 & 0.14587 \\ \text { East } & 0.34637 & 0.706 & 0.24797 \\ \text { South } & 0.32062 & 0.632 & 0.32901\end{array}$

Occupation in the latter job. Reference category: professional...

$\begin{array}{llll}\text { Occu3 } & -0.77123 & -2.167 & 0.3209 \\ \text { Occu4 } & -0.52597 & -1.347 & 0.11507 \\ \text { Occu5 } & -1.3368 & -2.932 & 0.16207 \\ \text { Occu6 } & -0.76199 & -2.022 & 0.20746\end{array}$

Socio-economic category of latter job. Reference category: employer
Sit2
$-4.1653$
$-4.700$
Sit3
$-4.2905$
$-10.687$
$0.64830 \mathrm{E}-0$
0.84117

Education. Reference category: primary education
Ed2
$0.4274 \mathrm{E}-01$
0.150
0.63047
$\mathrm{Ed} 3$
$-0.572 \mathrm{E}-01$
$-0.149$
0.12156
Ed4
$-0.70259$
$-1.408$
$0.5186 \mathrm{E}-01$

Age. Reference category: 16-28
Age2
Age 3
$-0.18030$
$-0.757$
0.48784
Age4
$-0.26970$
$-0.913$
0.20097
0.237
0.13290

Type of household. Reference category: household without children
T-house
$-0.314 \mathrm{E}-01$
$-0.163$
0.38250

Situation of principal earner. Reference category: inactive and unemployed
SitCF
0.15209
0.664
0.74392

Unemployment benefits. Reference category: don't receive it

\begin{tabular}{llrl} 
Ubenef & 0.67286 & 3.663 & 0.61426 \\
$\mu 1$ & 1.0945 & 12.059 & \\
$\mu 2$ & 1.7899 & 15.217 & \\
$\mu 3$ & 2.6151 & 15.426 & \\
\hline
\end{tabular}

Notes: $N=617$.

Log-likelihood $=-736.2745$.

Restricted (slopes $=0$ ) Log- $\mathrm{L}=-894.0546$.

Chi-squared $(21)=315.5602$. 
Northwest and East of Spain. In addition, it is found that the probability of unemployment is significantly higher in medium and large towns than in small towns. The reason behind this fact is that although mobility between regions is low, mobility from rural areas to urban areas is relatively high. The greater participation of women in rural than in urban areas, because of their participation in agriculture and family work, coexists with a saturation of the labour market in urban areas that are the recipients of unemployed people moving from rural areas in search of new job opportunities. This produces a saturation of urban labour markets, thus increasing the probability of unemployment for women in urban areas, with respect to rural areas.

\subsection{Unemployment duration equation}

The estimated coefficients of the ordered logit model for unemployment duration steps appear in Table 11.

Neither the regional variables nor the size of the town (Stown) make a significant contribution to increasing duration of unemployment in relation to their corresponding reference category (Madrid region and small towns under 20,000 inhabitants, respectively).

Similarly, neither environmental or socio-economic factors nor personal characteristics like educational attainment differ significantly in their contribution to unemployment duration. In other words, there seems to be no difference in unemployment duration between a woman with secondary education and a woman with primary school education, which is the reference category. None of the education-related variables are statistically significant, although the sign is negative, as expected, and the significance is comparatively higher for the two top levels. Also, the age variable dummies (Age2, Age3 and Age4) do not show significant differences with respect to the youngest age group (under 28 years old). These results contrast with the significant impact of the age and education dummies on the probability of unemployment. They suggest that, conditional on being unemployed, staying in the unemployment pool does not differ among age groups or educational levels. On the other hand, our initial presumption that living with a partner in employment would have a negative impact on unemployment duration, does not show any significant influence according to our estimates (the $t$-ratio of SitCF has an associated $p$ value of 0.506 ). 
Labour market factors have a significant impact on unemployment duration. Occupational category variables (Occu variables) all have (but one) negative significant contributions to unemployment duration. In particular, agricultural and related workers is the occupational group which appears with a more negative estimated coefficient in relation to the reference category, which is formed by professionals, legislators and managers. The same happens with socio-economic situation (Sit dummies). Both employees and family workers have a negative impact on unemployment duration in comparison with self-employed and employers, which is the reference category. It is interesting to note that this result is in line with the expectation of a greater protection from unemployment if the woman is a labour market dependent than if the woman is on her own in the labour market, especially if she, as most probably is the case, depends on a small business.

Finally, the receipt of unemployment benefit (see the variable Ubenef) has a positive impact on unemployment duration among women. This is a standard result, which can be explained by the increase in the reservation wage where the unemployed person is subsidized, thus increasing the average duration of unemployment.

\section{Concluding remarks}

Evidence from the developments of female unemployment over the period 1983-92 shows that the unemployment of women belonging to the central age groups has increased at the same pace or even more in percentage terms during the upswing than during the recession in Spain, as greater labour demand draws on the supply of 'discouraged' women. This suggests the importance of demand-side rather than supply-side variables for the explanation of unemployment of married women. In particular, the high percentage of women among those with temporary contracts made them more vulnerable to unemployment due to the ending of the contracts.

The suggestion that supply-side variables ought to be given a weaker role is underscored by the central point made in this paper, namely that both education and labour market experience are likely to protect women from unemployment less effectively than is suggested by some of the literature ${ }^{7}$ in a context where discouraged unemployment is high. 
Two equations for the probability of unemployment of married women were estimated. The first uses the sample of women participants with previous labour market experience. In the second equation, an additional regressor (the Mill ratio) was included to correct for sample selection bias. This allows us to compare the effect of education on women, conditioned on participation, with the effect of education unconditional on their participation in the labour market.

Our most interesting result relates to the differences in these two effects. While our estimates confirm that, irrespective of labour market participation, the more educated a married woman is, the less likely she is to become unemployed, the positive effect of education is higher if we concentrate our attention on women who are already participating in the labour force. In fact, given that female non-participants include both women who genuinely do not want to participate as well as women who are discouraged and, consequently could be considered as unemployed, the real impact of the age and education factors would be between both estimates - lower, in any case, than the conditional estimates obtained in the unemployment equation in Table 10. In other words, if all nonparticipating female spouses belonged to the first class, conditional estimates would give us the complete view, because in this case the participation decision would be independent of the probability of unemployment.

Even if estimates conditioned on participation do not tell us the whole story of the impact of education on unemployment of women spouses, as some of them will not be discouraged unemployed but non-participants, at least a more complete picture of the impact of some supply-side variables (education and age) is offered in this paper. Given that the educational safeguard against unemployment is in fact weaker than it seemed to be at first sight, married women with high educational attainment may also be discouraged from labour market participation by high unemployment rates.

The policy implications of our findings can be summarized as follows: in order to combat unemployment of women in Spain, the traditional measures to improve employability, such as education and training, are insufficient. Measures addressed to the reconciliation of family and professional life are required in order to achieve the full integration of Spanish women in the labour force. 


\section{Notes}

${ }^{1}$ A comparative analysis by Bettio and Villa (1993) carried out on a group of OECD countries shows the emergence of a distinctive path of female emancipation in Southern European countries due to the peculiarities of both the Mediterranean family and a late process of development, characterized by high unemployment, fertility at historical minima and low female participation in the labour market.

${ }^{2}$ A study of OECD countries argued that the growth of unemployment for many of the countries can be attributed to major shifts in the demand for labour by skill, caused by technological innovation (Jackman, 1995).

${ }^{3}$ Gönül (1992) goes on to state that 'The discrepancy between males and females can be explained by the fact that women have been culturally trained to stay at home and take care of children. Therefore, when they are at home they are clearly not searching; not that men work more than women, just that women 'traditionally are more aware of whether they are searching for a job' (p. 532).

${ }^{4}$ According to Archano (1993), the differential in the number of temporary contracts between men and women is an adequate indicator of labour market inequality. These contracts are very sensitive to recession, as they are cheap and easily eliminated during the downswing. In fact, they were promoted in order to make the firing process more flexible which, in Spain, is relatively expensive in terms of time and cost.

${ }^{5}$ Some evidence of the decreasing probability of women exiting the unemployment pool when living in households with other family members in unemployment and, conversely, the probability of exiting increasing when living in households with other family members in employment, is provided in Toharia (1993) and Ahn and Ugidos (1995).

${ }^{6}$ Note that the participation equation to be estimated assumes fertility to be exogenous, as most of the female labour supply literature used to do in the past. Unless fertility is treated as endogenous, and a simultaneous equation estimation technique is used, the estimates of wage and income effects will be inconsistent, as Rosenzweig and Wolpin (1980) have shown. However, as the participation equation is used to correct the sample selection bias and not to study the participation decision itself, this does not make any difference to the present authors' results.

${ }^{7}$ Mincer (1993) shows that the inverse relationship between education and unemployment of women is as strong as it is in the male labour force.

\section{References}

Ahn N. and Ugidos A. (1995) 'Duration of Unemployment in Spain: Relative Effects of Unemployment Benefit and Family Characteristics', Oxford Bulletin of Economics and Statistics 57(2): 249-264.

Andrés J., García J. and Jiménez S. (1989) 'La Incidencia y la Duración del Desempleo Masculino en España', Moneda y Crédito 189: 75-124.

Archano M. T. (1993) 'Información Estadistica sobre Desigualdad Social', I Simposio sobre Igualdad y Distribución de la Renta y la Riqueza, Fundación Argentaria, Madrid. 
Bettio F. and Villa P. (1993) 'Strutture Familiari e Mescati del Lavoro nei Paesi Sviluppati. L'emergere di un Percorso Mediterraneo per l'integrazione delle Done nel Mercato del Lavoro', Economia e Lavoro 27(2): 3-30.

De Miguel Castaño C. (1991) 'Tendencias y Perspectivas de la Participación Femenina en la Actividad Económica', Revista de Economía y Sociología del Trabajo 13-14 (September-December): 43-60.

García J., Polo C. and Raymond J. L. (1986) 'Principales rasgos del Desempleo Masculino en España', Papeles de Economía Española 26: 91-107.

García Serrano C. and Toharia L. (1994) 'Paro y Formación Profesional: un Análisis de los datos de la Encuesta de población Activa', Working Paper WP-EC 96-06, Instituto Valenciano de Investigaciones Económicas.

Gönül F. (1992) 'New Evidence on Whether Unemployment and Out of the Labor Force are Distinct States', Journal of Human Resources XXVII(2): 329-361.

Gracia-Díez M. (1991) 'A Qualitative Analysis of Unemployment in Spain', Labour 5(2): 159-173.

Greene W. H. (1993) Econometric Analysis, 2nd edn, London: Macmillan.

Holzer H. J. (1988) 'Search Methods Used by Unemployed Youth', Journal of Labor Economics 6: 1-20.

Jackman R. (1995) 'Unemployment and Wage Inequality in OECD Countries', Discussion Paper 235, Centre for Economic Performance, London School of Economics.

Maddala G. S. (1983) Limited Dependent and Qualitative Variables in Econometrics, Cambridge: Cambridge University Press.

Mincer J. (1993) 'Education and Unemployment of Women' in Mincer, J. (ed.) Collected Essays of Jacob Mincer, Vol. 2. Studies in Labor Supply. Economists of the Twentieth Century series, Cheltenham: Edward Elgar: $187-206$.

Moltó M. L. (1994) 'Changing Patterns of Work and Working-time for Men and Women in Spain: Towards the Integration or the Segmentation of the Labour Market?' in Report for the Network of Experts on the Situation of Women in the Labour Market, Brussels: Commission of the European Communities.

Moltó M. L. (1995) 'Women and the Employment Rate in Spain: The Causes and Consequences of Variations in Female Activity and Employment Patterns', Report for the Network of Experts on the Situation of Women in the Labour Market, Brussels: Commission of the European Communities.

Moltó M. L., Peraita, C., Sánchez, M. and Uriel, E. (1994) 'Método e Intensidad de Búsqueda de Empleo en los Desempleados', Revista de Economía Aplicada II(4): 53-74.

Novales A. (1989) 'La Incorporación de la Mujer al Mercado de Trabajo en España: Participación y Ocupación', Moneda y Crédito 188: 243-289.

Rosenzweig M. R. and Wolpin K. I. (1980) 'Life-cycle Labour Supply and Fertility: Causal Inferences from Household Models', Journal of Political Economy 88(2): 328-348.

Toharia L. (1991) 'El Paro Femenino en España: Algunos Elementos para el Análisis', Revista de Economía y Sociología del Trabajo 13-14: 74-87.

Toharia L. (1993) 'Familia y Paro' in Garrido Medina, L. and Gil Calvo, E. (eds.) Estrategias Familiares en un Mundo en Cambio, Madrid: Alianza Editorial: $316-334$. 